\title{
The institutional design, politics, and effects of a bioregional approach: observations and lessons from 11 case studies of river basin organizations
}

\author{
Sander Meijerink ${ }^{1}$ and Dave Huitema ${ }^{2,3}$
}

\begin{abstract}
One of the prescriptions for adaptive comanagement of social-ecological systems is to follow a bioregional approach. In water resources management, experience has been gained with a bioregional approach by the foundation of river basin organizations (RBOs). Here, we summarize the results of a research project involving 27 colleagues who have undertaken an analysis of the global discussion on RBOs and the foundation of RBOs in Canada, USA, Great Britain, Germany, Portugal, South Africa, Ukraine, Afghanistan, Mongolia, Thailand, and Australia. Drawing on Ostrom's institutional analysis and development framework, we first present a fine-grained analysis of the institutional architecture of these RBOs, which enables us to distinguish between autonomous, coordinating, partnership, and agency type RBOs. Second, we unravel the main controversies over this architecture by focusing on the key actors involved in either promoting or hindering RBO formation, globally and at the national level. Third, we summarize how the performance of RBOs can be evaluated in terms of coordination, accountability, legitimacy, and environmental effectiveness. Finally, we discuss the relationship between institutional design and performance. The main findings are: (1) the foundation of RBOs is not a neutral process but rather a highly political one, (2) the foundation of RBOs creates complex accountability relationships, and (3) institutional interplay, the capacity to generate financial resources, and a minimum degree of institutional stability are crucial to the successes of RBOs in realizing coordination and environmental effectiveness.
\end{abstract}

Key Words: accountability; bioregional approach; institutional analysis; institutional interplay; river basin organizations

\section{INTRODUCTION}

One of the prescriptions for the adaptive comanagement of socialecological systems is the bioregional approach. The core idea is that the management of ecological issues should be organized at the scale at which these issues manifest themselves. A good example of a bioregion is a river basin. The water resources management literature has long recognized that river basins are logical units for water resources management because of important relationships between upstream and downstream water uses and between land and water use within a basin. Because the boundaries of a river basin usually do not coincide with administrative boundaries, a large variety of institutional arrangements for river basin management have been developed. In the introduction to this special feature (Huitema and Meijerink 2017), we present an ideal typology of river basin organizations (RBOs), distinguishing between "autonomous," "agency," "coordinating," and "partnership" type RBOs. These ideal types represent four different ways in which a bioregional approach can be institutionalized. Here, we use this typology to characterize RBOs in 11 river basins across the globe. We include in-depth studies of four of these RBOs in this special feature: the Westcountry Rivers Trust in the UK (Cook et al. 2016), the Breede-Overberg Catchment Management Agency in South Africa (Meissner et al. 2016), the Mackenzie River Basin Board in Canada (Morris and de Loë 2016), and the Murray-Daring Basin Authority in Australia (Ross and Connell 2016). Information on the other RBOs can be found in Huitema and Meijerink (2014). To gain a better understanding of the process of RBO formation, we also analyze which actors supported or resisted the founding of RBOs. Finally, we will discuss the functioning of these RBOs in a democratic sense, both in terms of realizing coordination on a basin scale and in terms of environmental effectiveness. Based on these findings, we discuss the relationship between the institutional design and performance of RBOs.

\section{INSTITUTIONAL DESIGN CHARACTERISTICS OF RIVER BASIN ORGANIZATIONS}

\section{Results from the application of the ideal typology}

Table 1 gives an overview of the countries and the RBOs studied, combined with a characterization of these RBOs in terms of the typology, which we presented in the introduction to this special feature (Huitema and Meijerink 2017). As the typology consists of so-called ideal types in a Weberian sense, it was to be expected that none of the RBOs that we included in our study was exactly identical to the types we had identified. To mention just a few examples: the Oregon Watershed Enhancement Board is an agency type RBO because it was given a specific mandate by the State of Oregon, but at the same time, it shares some characteristics with both the coordinating and partnership type RBOs. The German case study of the so-called Erftverband is an example of an agency type RBO, but because of its fairly independent position and far reaching competencies, it also shares some characteristics with the ideal-type autonomous RBO. The same goes for most other RBOs that have been analyzed.

Although the collection of case studies presents a far from random sample of the total population of RBOs (the focus was on cases that the collected authors were already familiar with), it is worth reflecting on the types of RBOs that have been discussed in this collection (Table 1). Agency, coordinating, and partnership type RBOs are well represented, but only one example of an autonomous RBO is presented. The limited number of autonomous RBOs, which are characterized by their independent

${ }^{1}$ Institute for Management Research, Radboud University, ${ }^{2}$ VU University Amsterdam, ${ }^{3}$ Open University of the Netherlands 
Table 1. Characterization of the river basin organizations (RBOs).

\begin{tabular}{llc}
\hline \hline Country & Name of RBO & Type of RBO \\
\hline Canada & Mackenzie River Basin Board & Coordinating \\
United States of America & Oregon Watershed Enhancement Board & Agency \\
United Kingdom & Westcountry Rivers Trust & Partnership \\
Germany & Erftverband & Agency \\
Portugal & River Basin District Authorities & Autonomous \\
South Africa & Breede-Overberg Catchment Management Agency & Agency \\
Ukraine & Western Bug River Basin Administration & Agency \\
& Western Bug River Basin Council & Coordinating \\
Afghanistan & Lower Kunduz and Taloquan River Basin Agencies & Agency \\
& Lower Kunduz and Taloquan River Basin Councils & Coordinating \\
Mongolia & River Basin Councils & Coordinating \\
& River Basin Administrations & Agency \\
Thailand & Ping River Basin Committee & Coordinating \\
Australia & Mae Kuang Sub-basin working group & Coordinating \\
& Murray-Darling Basin Authority & Agency \\
& Murray-Darling Basin Ministerial Council & Coordinating \\
\end{tabular}

position in comparison to other government organizations, is perhaps not surprising because shifts in governance in the direction of this type are rare (Schlager and Blomquist 2008). However, the academic literature on RBOs shows a clear preference for autonomous governance (Huitema et al. 2009). A second observation is that in quite a number of cases, we found more than one RBO in the same basin; often the presence of more than one RBO takes the form of a combination of an agency and a coordinating type RBO. In these cases, the agency type of RBO is given a specific mandate by the national government, and the coordinating type of RBO aims to broker between subnational governments, policy sectors, and different societal interests. Following the account by Jaspers and Gupta (2014), we can conclude that such institutional layering is not unique for the cases that we have included in our study. Jaspers and Gupta (2014:44) refer to the "increasing density of the organisational framework that operates at multiple levels of governance and has multiple influences from different social actors." We conclude that the typology we proposed in the introduction to this special feature has proven useful for a basic characterization of the RBOs and works when one wants to position case studies comparatively in the institutional landscape. At the same time, the case studies display a rich institutional variety, layering, and complexity that cannot be captured easily by suggesting that in every case only a single type is present.

\section{Rules of all stripes}

Having concluded that the typology of RBOs that we developed is sufficient for a quick scan but has some limitations, we continue our analysis on the basis of the various rule types that were behind the typology for a more disaggregated analysis. We derived these types from Elinor Ostrom"s institutional analysis and development framework (Kiser and Ostrom 1982). Table 2 summarizes the authority, aggregation, boundary, information, and pay-off rules for each $\mathrm{RBO}$.

\section{Authority rules}

After comparing the authority rules of the RBOs, we observe that a distinction can be made between RBOs with a narrow mandate and those with a broad mandate. The Oregon Watershed
Enhancement Board, for instance, was founded only for the restoration of salmon habitat (Lach and Calvert 2014). In contrast, the German Erftverband has a broad mandate that covers groundwater and surface water management, water quality and quantity, sewerage, waste water treatment, planning, and monitoring (Hüesker and Bernhardt 2014). It should be noted, however, that the formal mandate that RBOs have is not always in line with the issues that they focus on in practice. The Afghan river basin agencies, for instance, have a very broad mandate on paper, but in practice, they focus on allocation issues only (Warner and Thomas 2014).

We can also conclude that the authorities acquired by RBOs can derive from multiple sources, and these are different for all types. The only autonomous RBO we encountered in our study (in Portugal) derived its authority directly from legislation adopted by Parliament. In the case of coordinating RBOs, the mandate depends on the willingness of the contracting parties to transfer power to the RBO (in the case of the Mackenzie River Basin Board [Morris and de Loë2016], these are the Canadian provinces that founded it). For agency type RBOs, the mandate depends on the willingness of the "principal" (see Waterman and Meier 1998) to delegate a certain number of authorities (for examples, see the Ukrainian [Hagemann and Leidel 2014] and Mongolian [Dombrowsky et al. 2014] River Basin Administrations and the Murray-Darling basin organization [Ross and Connell 2016]). In the case of partnership type RBOs, it is the founding members who decide on the scope of activities and decision-making power themselves (e.g., see Westcountry Rivers Trust; Cook et al. 2016).

Because the 11 case studies had a longitudinal perspective, we were also able to investigate whether patterns in their development are present, such as gradual institutionalization, development from coordinating RBOs to autonomous RBOs, or from a relatively small to a broad mandate. We did not observe any progressive or even consistent pattern of development in the cases studied. In fact, our observations rather confirm Jaspers and Gupta's (2014) statement that there is nothing linear in RBO development and that the evolution of every RBO is context specific. 
Table 2. Summary of authority, aggregation, boundary, information, and pay-off rules.

\begin{tabular}{|c|c|c|c|c|c|}
\hline $\begin{array}{l}\text { Name of river basin } \\
\text { organization }\end{array}$ & Authority rules & Aggregation rules & Boundary rules & Information rules & Pay-off rules \\
\hline $\begin{array}{l}\text { Mackenzie River } \\
\text { Basin Board }\end{array}$ & $\begin{array}{l}\text { Delegated mandate } \\
\text { focuses on } \\
\text { coordination, } \\
\text { facilitation, dispute } \\
\text { resolution, and } \\
\text { information gathering } \\
\text { and sharing; pertains to } \\
\text { ecological integrity and } \\
\text { sustainability }\end{array}$ & $\begin{array}{l}\text { Decisions require the } \\
\text { consent of two-thirds } \\
\text { of the members of the } \\
\text { Board }\end{array}$ & $\begin{array}{l}\text { Geographical } \\
\text { boundaries based on } \\
\text { hydrological criteria; } \\
\text { membership is limited } \\
\text { to representatives of } \\
\text { governments and to } \\
\text { Aboriginal peoples }\end{array}$ & $\begin{array}{l}\text { Emphasis on science } \\
\text { and traditional } \\
\text { knowledge; meeting } \\
\text { minutes not public }\end{array}$ & $\begin{array}{l}\text { Budget provided by the } \\
\text { "basin jurisdictions" }\end{array}$ \\
\hline $\begin{array}{l}\text { Oregon Watershed } \\
\text { Enhancement Board }\end{array}$ & $\begin{array}{l}\text { Delegated mandate for } \\
\text { salmon restoration; } \\
\text { coordinating and } \\
\text { nonregulatory roles; } \\
\text { mobilizing resources } \\
\text { and managing grants; } \\
\text { reporting of results }\end{array}$ & $\begin{array}{l}\text { Majority voting in the } \\
\text { Appointed Board }\end{array}$ & $\begin{array}{l}\text { Partnerships at the } \\
\text { watershed level (all } \\
\text { within Oregon); Board } \\
\text { members represent } \\
\text { different geographical } \\
\text { areas of the state }\end{array}$ & $\begin{array}{l}\text { Science and } \\
\text { experiential knowledge } \\
\text { valued; progress reports } \\
\text { public }\end{array}$ & $\begin{array}{l}\text { Budget provided by state } \\
\text { lottery money and } \\
\text { specific federal grants }\end{array}$ \\
\hline $\begin{array}{l}\text { Westcountry Rivers } \\
\text { Trust }\end{array}$ & $\begin{array}{l}\text { No formal authorities } \\
\text { delegated; aimed at } \\
\text { leveraging resources, } \\
\text { building collaborative } \\
\text { relations, and fulfilling } \\
\text { advisory and brokerage } \\
\text { roles }\end{array}$ & Consensus & $\begin{array}{l}\text { Boundaries defined on } \\
\text { the basis of } \\
\text { hydrological criteria } \\
\text { and water quality and } \\
\text { habitat issues; } \\
\text { voluntary and locally } \\
\text { inclusive participation }\end{array}$ & $\begin{array}{l}\text { Scientific, local, and } \\
\text { experiential knowledge } \\
\text { welcomed }\end{array}$ & $\begin{array}{l}\text { Costs and benefits } \\
\text { shared between } \\
\text { participants }\end{array}$ \\
\hline Erftverband & $\begin{array}{l}\text { Broad delegated } \\
\text { mandate includes water } \\
\text { quality management, } \\
\text { flood management, } \\
\text { sewerage and waste } \\
\text { water treatment, and } \\
\text { water supply }\end{array}$ & $\begin{array}{l}\text { Majority voting; } \\
\text { representation } \\
\text { according to the level } \\
\text { of contribution }\end{array}$ & $\begin{array}{l}\text { Boundaries set on the } \\
\text { basis of hydrological } \\
\text { criteria; mandatory } \\
\text { membership for water } \\
\text { users and polluters }\end{array}$ & Emphasis on science & $\begin{array}{l}\text { Water charges and tariffs } \\
\text { levied to members }\end{array}$ \\
\hline $\begin{array}{l}\text { Portuguese River } \\
\text { Basin District } \\
\text { Authorities and } \\
\text { Councils }\end{array}$ & $\begin{array}{l}\text { Financial and } \\
\text { administrative } \\
\text { autonomy; } \\
\text { coordination; } \\
\text { monitoring; provision; } \\
\text { dispute resolution }\end{array}$ & $\begin{array}{l}\text { Decision making in } \\
\text { councils is consensual }\end{array}$ & $\begin{array}{l}\text { Boundaries based on } \\
\text { hydrological and } \\
\text { ecological criteria; } \\
\text { municipalities and } \\
\text { users associations } \\
\text { represented }\end{array}$ & $\begin{array}{l}\text { Emphasis on science; } \\
\text { much emphasis on } \\
\text { information exchange } \\
\text { between government } \\
\text { layers }\end{array}$ & $\begin{array}{l}\text { Water charges and tariffs } \\
\text { levied to users }\end{array}$ \\
\hline $\begin{array}{l}\text { Breede-Overberg } \\
\text { Catchment } \\
\text { Management Agency }\end{array}$ & $\begin{array}{l}\text { Mandate for water } \\
\text { allocation, water } \\
\text { resources protection, } \\
\text { water use, development, } \\
\text { conservation, } \\
\text { management, and } \\
\text { control }\end{array}$ & $\begin{array}{l}\text { Mix of elite and } \\
\text { consensus decision } \\
\text { making; strong focus } \\
\text { on egalitarianism }\end{array}$ & $\begin{array}{l}\text { Boundaries based on } \\
\text { natural hydrological } \\
\text { borders and financial } \\
\text { viability; inclusive } \\
\text { decision making }\end{array}$ & $\begin{array}{l}\text { Emphasis on scientific } \\
\text { knowledge; stakeholder } \\
\text { input solicited }\end{array}$ & $\begin{array}{l}\text { Water charges and tariffs } \\
\text { levied to users; seed } \\
\text { funding from the } \\
\text { Ministry of Water and } \\
\text { Environmental Affairs }\end{array}$ \\
\hline $\begin{array}{l}\text { Western Bug River } \\
\text { Basin Administration } \\
\text { (RBA) and Western } \\
\text { Bug River Basin } \\
\text { Council (RBC) }\end{array}$ & $\begin{array}{l}\text { Delegated mandate to } \\
\text { collect data and to } \\
\text { develop water } \\
\text { management plans, } \\
\text { including specific } \\
\text { measures }\end{array}$ & $\begin{array}{l}\text { RBC takes decisions on } \\
\text { the river basin plan by } \\
\text { majority rule; State } \\
\text { Agency for Water } \\
\text { Management has veto } \\
\text { power }\end{array}$ & $\begin{array}{l}\text { Boundaries based on } \\
\text { hydrological } \\
\text { boundaries of surface } \\
\text { waters; members are } \\
\text { regional and local } \\
\text { authorities, } \\
\text { nongovernmental } \\
\text { organizations (NGOs), } \\
\text { industrial } \\
\text { representatives, and } \\
\text { scientists }\end{array}$ & $\begin{array}{l}\text { Emphasis on science; } \\
\text { NGO input solicited }\end{array}$ & $\begin{array}{l}\text { State funding for RBA } \\
\text { staff and } \\
\text { implementation; } \\
\text { additional funds from } \\
\text { local government, } \\
\text { charges and tariffs, and } \\
\text { international donors }\end{array}$ \\
\hline $\begin{array}{l}\text { Lower Kunduz and } \\
\text { Taloquan River Basin } \\
\text { Agencies and Lower } \\
\text { Kunduz and } \\
\text { Taloquan River Basin } \\
\text { Councils }\end{array}$ & $\begin{array}{l}\text { Delegated mandate to } \\
\text { deal with a variety of } \\
\text { water issues (in } \\
\text { practice, addressing } \\
\text { water allocation only) }\end{array}$ & $\begin{array}{l}\text { Water users as key } \\
\text { decision makers (in } \\
\text { practice, use of } \\
\text { traditional "Abandaz" } \\
\text { system) }\end{array}$ & $\begin{array}{l}\text { Boundaries nominally } \\
\text { based on hydrological } \\
\text { criteria; formally, very } \\
\text { inclusive decision } \\
\text { making }\end{array}$ & Emphasis on science & $\begin{array}{l}\text { Reasonable upstream- } \\
\text { downstream equity }\end{array}$ \\
\hline
\end{tabular}




\begin{tabular}{|c|c|c|c|c|c|}
\hline $\begin{array}{l}\text { Mongolian River } \\
\text { Basin Councils } \\
\text { (RBCs) and River } \\
\text { Basin } \\
\text { Administrations } \\
\text { (RBAs) }\end{array}$ & $\begin{array}{l}\text { Delegated mandate to } \\
\text { coordinate activities of } \\
\text { public and private } \\
\text { parties in the basin, to } \\
\text { draft river basin } \\
\text { management plans, and } \\
\text { to grant water licenses; } \\
\text { RBCs responsible for } \\
\text { public participation } \\
\text { and monitoring of } \\
\text { water use and pollution } \\
\text { (through RBAs and } \\
\text { other organizations); } \\
\text { RBCs formulate } \\
\text { recommendations to } \\
\text { RBAs }\end{array}$ & $\begin{array}{l}\text { RBAs prepare river } \\
\text { basin management } \\
\text { plans, which need } \\
\text { formal approval of } \\
\text { provincial and district } \\
\text { parliaments; RBCs may } \\
\text { submit proposals for } \\
\text { suspending the RBA's } \\
\text { decisions }\end{array}$ & $\begin{array}{l}\text { Boundaries based on } \\
\text { hydrological, } \\
\text { socioeconomic, and } \\
\text { political criteria; } \\
\text { stakeholder-based } \\
\text { representation in the } \\
\text { RBCs }\end{array}$ & $\begin{array}{l}\text { Emphasis on science; } \\
\text { stakeholder input } \\
\text { solicited; sharing of } \\
\text { data not yet fully } \\
\text { regulated }\end{array}$ & $\begin{array}{l}\text { Charges and tariffs, state } \\
\text { funds, provincial funds, } \\
\text { and international donors }\end{array}$ \\
\hline $\begin{array}{l}\text { Ping River Basin } \\
\text { Committee and Mae } \\
\text { Kuang Sub-basin } \\
\text { working group }\end{array}$ & $\begin{array}{l}\text { Limited delegated } \\
\text { mandate for } \\
\text { coordination and } \\
\text { planning }\end{array}$ & $\begin{array}{l}\text { Join decision making } \\
\text { but with a strong } \\
\text { editing function of } \\
\text { traditional line-agencies }\end{array}$ & $\begin{array}{l}\text { Boundaries based on } \\
\text { hydrological } \\
\text { considerations; state } \\
\text { and nonstate actors } \\
\text { have access }\end{array}$ & $\begin{array}{l}\text { Emphasis on science; } \\
\text { few requirements to } \\
\text { share information } \\
\text { publicly }\end{array}$ & $\begin{array}{l}\text { State funding through } \\
\text { line agencies }\end{array}$ \\
\hline $\begin{array}{l}\text { Murray-Darling } \\
\text { Basin Authority, } \\
\text { Murray-Darling } \\
\text { Basin Ministerial } \\
\text { Council (MDBMC), } \\
\text { and Basin community } \\
\text { committee }\end{array}$ & $\begin{array}{l}\text { Delegated mandate for } \\
\text { water allocation } \\
\text { through planning for } \\
\text { and advising to the } \\
\text { government in the field } \\
\text { of water allocation }\end{array}$ & $\begin{array}{l}\text { The Australian } \\
\text { Government Minister } \\
\text { (who is accountable to } \\
\text { the Parliament of } \\
\text { Australia) decides on } \\
\text { the Basin Plan; decision } \\
\text { making in MDBMC } \\
\text { and basin community } \\
\text { committee is based on } \\
\text { consensus }\end{array}$ & $\begin{array}{l}\text { Boundaries based on } \\
\text { hydrological } \\
\text { considerations; } \\
\text { governments decide, } \\
\text { with nonstate actors } \\
\text { consulted }\end{array}$ & $\begin{array}{l}\text { Emphasis on science; } \\
\text { stakeholder input } \\
\text { solicited; data managed } \\
\text { centrally }\end{array}$ & $\begin{array}{l}\text { Government funding; } \\
\text { emphasis on water } \\
\text { markets }\end{array}$ \\
\hline
\end{tabular}

Mongolian River Basin Councils Administrations (RBAs)

\section{Aggregation rules}

In international RBOs, the decision-making rule is unanimity in most cases. Because of the absence of central authority, the socalled "international anarchy" (Sebenius 1992), basin states need to reach a consensus to conclude international agreements or decide on plans and policies. In our case studies, the emphasis was on cases located within countries. Interestingly, we find that for such cases, consensus is also frequently used as an aggregation rule (Table 2; e.g., Westcountry Rivers Trust, a partnership type of RBO [Cook et al. 2016], as well as most coordinating RBOs). However, other aggregation rules are also applied; majority voting was found in a number of cases, e.g., Mackenzie River Basin Board (Morris and de Loë 2016), Oregon Watershed Enhancement Board (Lach and Calvert 2014), and Western Bug River Basin Council (Hagemann and Leidel 2014). In the German Erftverband case, we find majority voting linked to a principle that assigns greater voting powers to those that pay more to the RBO (see Hüesker and Bernhardt 2014). The Ping River Basin Committee and the Mae Kuang Sub-basin working group in Thailand are examples of platforms dominated by line agencies. They essentially are the only relevant voters, and their power is further underpinned by their control over financial resources, which they can withhold from the RBO to effectively block implementation of RBO policies (Ganjanapan and Lebel 2014).

\section{Boundary rules}

In our analysis of boundary rules, we made a distinction between the rules describing the geographical delineation of the RBO and the inclusiveness of the RBO's decision-making processes. When comparing the geographical boundaries of the RBOs, the difference in scale of the basins studied stands out. The surface area of the basins studied ranges from the small Mae Kuang watershed in Thailand (1661 $\mathrm{km}^{2}$; Ganjanapan and Lebel 2014) to the massive Mackenzie River basin (18 million $\mathrm{km}^{2}$; Morris and de Loë 2016). We find that scale does matter: it actually appears to have an effect on the available options in terms of institutional design. For example, organizing a meeting of the basin board in the Mackenzie basin, let alone a full-blown multistakeholder process, is a laborious process, if only because of the immense travel distances. Indeed, the partnership type RBO is exclusively found at the level of relatively small basins. For the larger basins such as the Mackenzie and Murray Darling basins, coordinating or agency types of RBOs would appear to be the most feasible type.

In accordance with Schlager and Blomquist's (2008) and Molle and Wester's (2009) contention that the definition of the RBO's geographical scope and basin boundaries is not a straightforward technical or scientific exercise, but rather, a process in which other factors often also play a role, we found ample evidence that the geographical scope of the RBOs is determined by different criteria than purely hydrological ones. In the Mongolian case study, apart from hydrological criteria, economic and political factors played a role in defining the geographical scope of the RBOs: "Economically relevant rivers were granted the status of discrete river basins even when, from a hydrological perspective, they actually belonged to larger catchments" (Dombrowsky et al. 2014:271). In the Afghan case, the geographical delineation of the RBOs also does not match hydrological borders. Where subbasins proved either too big or were considered too heterogeneous 
in terms of land use, they were split up. Other relevant factors, which played a role in the delineation made by the founders, were the transport costs to attend meetings, the number of council seats, and the anticipated income through fee collection (Warner and Thomas 2014). In the South African case study (Meissner et al. 2016), next to hydrological criteria, the potential for a catchment management agency to achieve financial viability in the medium to long term already was and has recently become an even more important criterion for delineating the geographical boundaries of the RBOs.

Our cases confirm previous suggestions that even from a water centric perspective, it is not easy to delineate a river basin, for instance, because surface waters might be connected and groundwater aquifers not (or vice versa). Our case studies show that this can be a complicating factor in defining the basin boundaries. Occurrences of this can be found in the case studies on the Erftverband (Hüesker and Bernhardt 2014) and the Western Bug River Basin Administration (Hagemann and Leidel 2014). As Dombrowsky et al. (2014:271) explain, in the southern part of Mongolia, the Gobi Desert, there is no surface water, and because "not enough was known about the groundwater aquifers for the catchment areas to be defined, the river basins were defined by reference to provincial boundaries." Thus, even if there is a willingness to take natural relations into account, the information on what those are may simply not be available. In other cases such as the Mackenzie River Basin Board, the definition of the basin boundaries has not been an issue (Morris and de Loë 2016). This may be because of the low population density and the lack of political controversies in the border areas of the basin (and perhaps the fact that the RBO there is without much real clout). Interestingly, even if criteria other than hydrological criteria have proven important for defining the geographical scope of most RBOs studied, we have actually not found much evidence for power struggles or political conflict over the geographical boundaries of the RBO jurisdictions. The expectation of political bickering did not materialize in our cases; in its place was pragmatism: in all basins studied here, parties are pragmatic enough to define basin boundaries on the basis of criteria other than hydrological when it is necessary or considered useful.

The second type of boundary rules concerns the inclusion (or exclusion) of parties in decision-making processes. The findings on this rule type are directly related to the type of RBO studied, which suggests that this rule type is a strong indicator of the type of organization in question. The Westcountry Rivers Trust, as an example of a partnership, is characterized by voluntary and broad participation of societal stakeholders (Cook et al. 2016). In contrast, an interstate coordinating RBO such as the MacKenzie River Basin Board includes governmental and First Nations representatives only (Morris and de Loë 2016). Even though decision making in the coordinating RBOs may seem fairly inclusive, more often than not, considerable power remains with the state. In the South African case study, this power is reflected in the state's authority to determine the composition of the catchment management board. Meissner et al. (2016) argue that this state power is probably required to manage the challenge of power differences between vested economic interests and marginalized parties.
In the cases discussed here, we do not really see evidence of a shift in governance, that is, relocation of authority and power from the nation state to subnational governments or civil society. The partnership case of the Westcountry Rivers Trust may serve as an example; there, analysis shows that the Trust/RBO is complementing rather than replacing the existing, traditional, hierarchical, governmental institutions (Cook et al. 2016). It would thus seem safe to conclude that in terms of Thelen's (2004) terminology, the foundation of RBOs is normally not an example of institutional "displacement," which is associated with power shifts in the here and now. Instead, the foundation of RBOs can be better qualified in terms of "layering," i.e., the foundation of a new institution on top of existing ones, and a process that is associated with existing systems that are actually "intractable for change" in the short term and can only be changed in the long term, perhaps as a consequence of the new institution (Comodomos and Ferrer 2011). If anything, most of our cases demonstrate how extremely cautious existing institutions are and how careful they are to curtail the powers of the new RBOs by arranging for institutional designs that effectively constrain (some might say straightjacket) new RBOs. Unlike the discussion on geographical scope and basin boundaries, this is a highly political process.

\section{Information rules}

Information rules regulate the use of specific types of expertise, data, and information, as well as the openness of data and information on the status of the basin, and they also pertain to monitoring and information on the effectiveness of basin policies to the public. Based on the 11 case studies, we conclude that scientific expertise (which may relate to all natural sciences, including ecology but also engineering) really takes center stage in the design of almost all RBOs because it is almost universally considered the most relevant source of information for decision making, monitoring, and reporting. Conversely, experiential knowledge, be it local, indigenous, or professional knowledge, was hardly ever considered relevant by those that set up and designed RBOs, although many RBOs do have to meet a requirement to solicit knowledge from groups that have such knowledge (farmers, fishers, inhabitants). These observations are largely in line with the observation that Jaspers and Gupta (2014) make: water management is normally considered a highly technical field. Indeed, the examples of (often Western) nongovernmental organizations and donor countries trying to help establish RBOs show that such RBOs are expected to work almost exclusively on the basis of scientific information while largely ignoring the traditional and local knowledge embedded in the existing institutions for water management, even if later on it turned out to be essential for the functioning of the water regime. For example, the case of Afghanistan reveals how the Afghan "Abandaz" system comprising informal institutions to deal with upstream-downstream disputes was hardly recognized by the new institutional architects (Warner and Thomas 2014).

The selected cases show that attention to other forms of knowledge is more likely to emerge in partnership type RBOs (see Lach and Calvert 2014, Cook et al. 2016), perhaps because different partners with varied expertise are brought on board. Experiential expertise is brought in, and narrative anecdotes such as those about success stories play a key role in the functioning 
of the Oregon Watershed Enhancement Board (Lach and Calvert 2014). The Canadian example of the Mackenzie River Basin Board shows the relevance of clear requirements to incorporate traditional(Aboriginal) ecological knowledge (Morris and de Loë 2016).

Finally, and further underpinning our observation that the foundation of RBOs leads to the layering of institutions, the case studies also pointed to the politics of information. Even in cases in which the exchange of information across levels and sectors was a main objective, such an exchange was hindered by resilient existing institutional practices that are hostile to such an exchange. According to Hagemann and Leidel (2014:219), crosssectoral information exchange in the Ukraine is hampered because "[...] historically, communication is organized on a vertical axis. This means that data travels up from lower to higher level authorities, but not horizontally between different sectors." The foundation of the RBO was supposed to change existing information rules, but this may only become visible in the longer term.

\section{Pay-off rules}

The case studies display a rich variety of pay-off rules. These relate to the various ways in which the staffing of the RBO is financed, the funding of the policies and measures proposed by the RBO, and the distribution of costs and benefits among RBO members. Here too, we see quite a few attempts of existing organizations to keep the powers of the new RBOs in check: Most RBOs studied for our comparative analysis are expected to operate on a shoestring or need to request others to spend money in line with their plans and policies.

There are various mechanisms and procedures for setting budgets. For the management of the Australian Murray Darling basin, the jurisdictions rely on a negotiated intergovernmental cost-sharing formula that is supplemented by funding from the Australian government (Ross and Connell 2016). The Oregon Watershed Enhancement Board receives a fixed percentage of the revenues from the state's lottery (Lach and Calvert 2014). In still other cases, the user- and polluter-pays principles are used as a means to allocate costs and benefits among water users. In the German Erftverband, members generally contribute according to the amount of water used or polluted (but there are exceptions for mining companies; Hüesker and Bernhardt 2014). In the Westcountry Rivers Trust, payments for ecosystem services is practiced as an alternative to the polluter-pays principle (Cook et al. 2016). Two or more parties voluntarily reach an agreement on the provision and payment for ecosystem services, such as farmers providing water quality services to drinking water companies. This specific case provides a good example of the ways in which self-governance and self-organization can operate, albeit with a certain level of financial aid from the government (by means of subsidies). Within the substantially different context of Afghanistan, upstream and downstream water users sometimes manage to reach an agreement voluntarily on the temporary release of water by upstream water users to benefit parties downstream and thus achieve a reasonable upstream-downstream equity (Warner and Thomas 2014).

The case studies of developing countries reveal the crucial importance of financial resources provided by international donor organizations for the functioning of RBOs. The problem in these cases is often that resources for staffing the RBOs are provided and the planning stage is covered, but sufficient resources for realizing policy measures are lacking.

Summarizing, the fine-grained institutional analysis of RBOs revealed that there is no linear pattern of $\mathrm{RBO}$ development, the decision-making rule usually is unanimity or consensus, the geographical scope of most RBOs is not based on hydrological criteria only, and scientific knowledge plays a pivotal role in decision making. The cases studied do not exemplify a shift of power from the nation state to the RBOs. They rather indicate that RBOs are an example of institutional layering.

\section{INSTITUTIONAL DYNAMICS AND THE POLITICS OF RIVER BASIN ORGANIZATION FORMATION AND REFORM}

\section{Introduction}

Now that we have discussed and compared the main institutional features of the RBOs, we move on to the second research question addressing the process of RBO formation and reform. As we have outlined in the introduction to this special feature, beforehand we expected some actors such as the international water expert community, environmentalists, and downstream actors to be important advocates for the foundation of RBOs, and other parties such as general purpose governments, economic interests, and upstream actors to be less interested in this.

In our comparative study, we found ample evidence for the highly political nature of RBO formation and reform processes and the crucial role of change agents therein, but we also learned that the actions of these agents interact with specific events or triggers, which, in the literature, are often referred to as windows of opportunity (Kingdon 1995, Huitema and Meijerink 2009). Table 3 lists the main windows of opportunity and the actors pushing or hindering RBO formation and reform for each case study. We found that three (sometimes related) categories of windows of opportunity have played a role: problem windows, political windows, and windows related to the adoption of new legislation.

Triggers for river basin organization design and reform: reactions to shortcomings

What stands out in most of the case studies discussed here is that institutional reform proposals are often a reaction to observed shortcomings of the institutional design in place previously. The typical pattern is that these shortcomings have become clear after a shock or focusing event or because of persistent water management problems. In the Canadian case study, concerns related to the effects of upstream development on the PeaceAthabasca Delta (in the context of a relatively positive climate for interprovincial collaboration that has vanished since then) led the governments of British Columbia, Alberta, Saskatchewan, Yukon, and the Northwest Territories to recognize the need to coordinate and establish the Mackenzie River Basin Liaison Committee (Morris and de Loë 2016). In the German case study of the Erftverband, strongly intensified brown coal mining in the 1950 s and the related problems of distributing groundwater resources between municipalities and mining companies were the main triggers for legally strengthening the RBO, and when new challenges such as water pollution were recognized later, the scope of activities of the RBO was broadened (Hüesker and Bernhardt 2014). In the Mongolian case study, environmental degradation, 
Table 3. Windows of opportunity and actors pushing or hindering the founding and reform of river basin organizations.

\begin{tabular}{|c|c|c|c|}
\hline Name & Windows of opportunity & Pushing actors & Hindering actors \\
\hline Mackenzie River Basin Board & $\begin{array}{l}\text { Problem: drying out of the Peace- } \\
\text { Athabasca Delta }\end{array}$ & $\begin{array}{l}\text { Federal and state governments, but } \\
\text { primarily the downstream } \\
\text { Northwest Territories }\end{array}$ & $\begin{array}{l}\text { Upstream provinces refuse to grant } \\
\text { more power to the Board }\end{array}$ \\
\hline $\begin{array}{l}\text { Oregon Watershed Enhancement } \\
\text { Board }\end{array}$ & $\begin{array}{l}\text { Legislation: U.S. Endangered Species } \\
\text { Act listing of salmon species }\end{array}$ & Governor of Oregon & $\begin{array}{l}\text { Environmental groups who preferred } \\
\text { legal obligations to restore habitat } \\
\text { above voluntary action; republican } \\
\text { legislators because of use of funds } \\
\text { for land acquisition }\end{array}$ \\
\hline Westcountry Rivers Trust & Problem: failure of existing & Among others, Arlin Rickard & None \\
\hline
\end{tabular}

Erftverband

Portuguese River Basin District Authorities and Councils

South African Catchment Management Agencies

Western Bug River Basin Administration and Council

Lower Kunduz and Taloquan River Basin Agencies and Councils

Mongolian River Basin Administrations and Councils

Ping River Basin Committee and Mae Kuang Sub-basin working group

Murray Darling Basin Authority institutions to solve pollution and habitat loss issues effectively Problem: issue of distribution of groundwater resources between municipalities and mining companies; later, new challenges such as water pollution Legislation: European Water Framework Directive

Political: the country's democratic transition

Political: the country's transitioning process after independence

Political: fall of the Taliban

Political: decentralization process after peaceful democratic revolution Problem: environmental degradation caused by rapid expansion of the mining sector

Problem: 1997-1998 financial crisis

Problem: existing arrangements proved insufficient to guarantee water supply during severe drought conditions such as in 2006-2007
State of North Rhine Westphalia enabled the foundation of "special law water boards"

Influential group of Portuguese water experts and a Minister who was part of this group

Minister of Water Affairs, Kadar Asmal

International (donor) organizations for example, the European Union through project TACIS Donor organizations: Germany's overseas agency for technical cooperation and Landell-Mills consultancy, both hired and funded by the European Union

World Wide Fund for Nature; Dutch Some local authorities who feared water experts; Mongolian water professionals trained in Eastern Europe

Asian Development Bank, World Bank, Global Water Partnership

Australian Government; for most issues, South Australia
Registered Society of Rhenish Brown Coal Plants considered establishment of the Erftverband unnecessary

Ministry of Finance, which feared greater costs; Regional Development and Coordination Commissions; technocrats within the national water institute

Technocrats within the Department of Water Affairs and Forestry and systems modelers opposing decentralization

Existing (hierarchical) institutional structures from Soviet times

Existing institutions such as the Governor and the traditional "mirab" and "Abandaz" systems they would have to finance new activities; powerful mining sector

Persistent bureaucratic competition is detrimental to the success of the river basin organization

State governments other than South Australia; farmer and irrigator groups which was caused by the rapid expansion of the mining sector, was a main trigger for RBO formation (Dombrowsky et al. 2014). In the Murray Darling case study, increased water use has led to increased salinity, substantial degradation of rivers and wetlands, and losses of native fish, and existing arrangements proved insufficient to guarantee water supply during severe drought conditions such as in 2006-2007 (Ross and Connell 2016). For these reasons, the Australian national government established a new Murray-Darling basin plan and a new organizational arrangement to implement it, including a new Murray Darling Basin Authority. Finally, the development of partnerships in the UK such as the Westcountry Rivers Trust was a reaction to the top-down implementation of the European Water Framework Directives by agency type RBOs and their failure to solve pollution and habitat loss issues effectively (Cook et al. 2016). In all these cases, failure of existing water management institutions to address urgent water management problems served as a main trigger for either establishing new or reforming existing RBOs. Finally, the Asian financial crisis was the window of opportunity that led to the involvement of donor agencies who were advocating the establishment of RBOs in Thailand (Ganjanapan and Lebel 2014).

In addition to persistent problems, new regulations or legislation may open a window of opportunity for those advocating institutional change. After the Governor of Oregon's bad experiences with the listing of the northern spotted owl under the U.S. Endangered Species Act and the resultant litigation, he first tried to prevent a listing of salmon species and later tried to develop an alternative, bottom-up, approach to the challenge of 
habitat restoration. According to one of the governor's staff members: "You don't recover salmon by issuing orders from Salem [Oregon's capital]. But you don't recover them with orders from D.C. either. People on the ground have to want to do it. You can't make them do it" (Lach and Calvert 2014:111). In a similar vein, the adoption of the European Water Framework Directive was exploited by high-level Portuguese policy entrepreneurs to see through their plans and to establish river basin district authorities (Thiel and Guerreiro de Brito 2014).

In still other cases, developments in the broader political environment opened a window for institutional innovation. Examples of these are the democratic transition of South Africa (Meissner et al. 2016), the fall of the Taliban in Afghanistan (Warner and Thomas 2014), the decentralization process after peaceful democratic revolution in Mongolia (Dombrowsky et al. 2014), and the transitioning process after independence in the Ukraine (Hagemann and Leidel 2014).

\section{Actors pushing or hindering river basin organization formation and reform}

Although the triggers or windows of opportunity described above may explain to some extent why initiatives for RBO formation or reform were taken, only the actors on the ground can interpret events, exploit windows of opportunity, and initiate institutional reform processes, or they can try to block or frustrate them. In our study, we came across five broad categories of actors who either pushed or hindered the founding or reform of RBOs (Table 3): upstream and downstream parties, parties having vested economic interests, political parties, general purpose governments, and international donor organizations.

\section{Upstream and downstream parties}

Diverging interests of upstream and downstream water users and related power asymmetries often translate into disagreements about RBO design. In the Mackenzie basin, the Government of the Northwest Territories, which is situated downstream of the other basin jurisdictions, has advocated changes in the Board's membership and funding so as to make the Board more effective, but reform proposals have not succeeded so far (Morris and de Loë 2016). Because the Mackenzie River Basin Board is a coordinating type of RBO, a downstream party such as the Northwest Territories always needs the cooperation of upstream parties and therefore is dependent on their willingness to cooperate. In the Australian case study, South Australia, the downstream basin state in the Murray-Darling basin, has an interest in maintaining downstream flows to ensure water supplies for the state, whereas the other states have supported diversions, especially for irrigation (Ross and Connell 2016). Likewise, in the Afghan case, the relationship between upstream and downstream water users is crucial for understanding the functioning of the RBO. Interestingly, the traditional Abandaz system, which was essentially disregarded by foreign donor organizations, was developed exactly for the purpose of solving allocation issues between upstream and downstream water users, making the decision to ignore the system even more perplexing (Warner and Thomas 2014). Clearly, hydro-politics does not only exist in the international context but is ubiquitous within states.

Parties with vested economic interests

As in other cases of institutional reform, the case studies included here demonstrate that parties with vested economic interests are often more interested in maintaining the status quo than in institutional reform. For example, in the German case study, the Registered Society of Rhenish Brown Coal Plants, representing the interest of the coal industry, considered legal establishment of the Erftverband unnecessary (Hüesker and Bernhardt 2014). The mining industry is an important actor in the Mongolian case study as well. Dombrowsky et al. (2014:286), quoting The Economist state, "Political support for improved control of the mining industry [to be achieved in part by the foundation of an $\mathrm{RBO}$ ] will most probably remain difficult as the sector is the largest contributor to the country's spectacular GDP [gross domestic product] growth over the last years." In the Australian case, farmer and irrigation groups are skeptical about the referral of Murray-Darling Basin management powers to Australian government (Ross and Connell 2016). The reason for this may be because they question the effectiveness of a more centralized river basin management, but also because they perceive such centralization as detrimental to their interests.

\section{Political parties}

The case studies produce some evidence for the role of party politics as well. In the case study of the Oregon Watershed Enhancement Board, Republican legislators opposed the use of funds for the expropriation of agricultural land to protect agricultural interests (Lach and Calvert 2014). In Australia, both main political parties on the national level supported the centralization of water policies, but on the state level, the liberal coalitions of Victoria, New South Wales, and Queensland all voiced similar criticisms in response to the basin plan that had been developed. One of the criticisms was around the uncertain environmental benefits of the basin plan (Ross and Connell 2016). The study of transformation of Portuguese RBOs illustrates how elections and changes in government have played a crucial role in the institutional reform processes, which has meant that the water governance system of Portugal has oscillated between two competing visions for years (Thiel and Guerreiro de Brito 2014). Finally, the Mongolian case study suggests that the increased influence of the Green party in that country may have been conducive to RBO formation (Dombrowsky et al. 2014).

\section{General purpose governments}

RBOs are an example of special purpose governments (Skelcher 2006). Unlike general purpose governments such as the nation state, provinces, or municipalities, RBOs are designed to address water management issues specifically. The founding of special purpose governments such as RBOs may come at the cost of the competencies of general purpose governments. As Jaspers and Gupta (2014:60) argue in their analysis of global discourse on RBOs: "[...] RBOs embody a power struggle - a shift of power from the state to an administrative body at both international and national level and this power struggle has often led to minimizing the mandate of the RBO." The case studies analyzed support these words (compare our preceding treatment of authority and information rules). The Australian case study exemplifies this power struggle: the states reluctantly accepted an increase in federal powers in return for increased federal contributions (Ross and Connell 2016). In the Ukrainian (Hagemann and Leidel 2014), Afghan (Warner and Thomas 2014), and Mongolian (Dombrowsky et al. 2014) case studies, existing (hierarchically operating) government agencies are hindering effective RBO formation. In Portugal, the Regional Development and 
Coordination Commissions opposed the founding of river basin administrations (Thiel and Guerreiro de Brito 2014). Although the tension between existing general purpose governments and newly created RBOs stands out in most cases, perhaps because RBOs are seen as a threat to institutional displacement, some RBOs such as the Oregon Watershed Enhancement Board (Lach and Calvert 2015) and the Westcountry Rivers Trust (Cook et al. 2016) not so much rival but complement existing institutions, which may explain why the struggle over competencies has been less prominent in these cases. This is an indication that an institutional layering strategy (Thelen 2004) meets with less resistance.

\section{International (donor) organizations}

Within our set of RBOs, there is a specific category in which international donor organizations have been the crucial actors pushing the concept of RBOs and the associated principles of organizing water management on a basin scale (bioregions) and undertaking such management in a participatory manner (referred to as "the holy trinity" by Warner and Thomas [2014]). Jaspers and Gupta (2014) mention the financial assistance and the attached conditions related to aid and development projects as one of several factors that explain why certain water management discourses are appealing.

Donor organizations, in turn, are influenced by international epistemic communities such as the World Water Council, Global Water Partnership, the International Law Association, and the engineering community (Jaspers and Gupta 2014). In our collection of case studies, the Ukraine (Hagemann and Leidel 2014), Afghanistan (Warner and Thomas 2014), Mongolia (Dombrowsky et al. 2014), and Thailand (Ganjanapan and Lebel 2014) are clear examples of the influence of international donor organizations on RBO formation. The authors of the Afghan case study are probably most critical of such organizations (Warner and Thomas 2014). They point to the lack of proper problem and institutional analyses and the inaccurate assumption that water governance in Afghanistan is a "blank slate." They illustrate the lack of a proper problem analysis with the example that "despite no intersectoral conflicts being reported, the PanjAmu river basin programme unhelpfully insisted in multi-user mapping" (Warner and Thomas 2014:240). According to Warner and Thomas (2014), the main reason for the Afghan government officials accepting the founding of RBOs as proposed by the EU was their interest in EU funding of water control infrastructure projects so that they could carry on with their longstanding "hydraulic mission" (which is in many ways the opposite of what the EU strives for in its own legislation such as the Water Framework Directive). International donors often do not work alone. For instance, in the Mongolian case study (Dombrowsky et al. 2014), international actors promoted the RBO concept, but the founding of RBOs was also supported by Mongolian water experts who were trained in Europe and Russia, thereby suggesting the importance of education in forming an epistemic community. The same concept applies to the Thai case study (Ganjanapan and Lebel 2014), where the Asian Development Bank, World Bank, and Global Water Partnership pushed the RBO concept, but the National Water Resources Committee endorsed RBO development.
The empirical findings about actors pushing or hindering $\mathrm{RBO}$ foundation are in accordance with our hypothesis that RBO formation is not a straightforward technical exercise but a highly political enterprise.

\section{PERFORMANCE OF RIVER BASIN ORGANIZATIONS}

\section{Introduction}

In the preceding sections, we compared the institutional design of RBOs and explored the political dimension of their founding and reform. We now shift our focus to the RBOs' performance. In the introduction to this special feature (Huitema and Meijerink 2017), we discussed criteria that may be used to assess RBOs' performance, and we questioned whether these organizations enhance (1) coordination across levels of government, policy sectors, and between public and private parties; (2) the accountability of water policies; (3) the legitimacy of water policies; and (4) the environmental effectiveness of policies (for the meaning of these criteria see our special feature introduction). Table 4 summarizes the findings about RBO performance for each case study. The assessment was qualitative, distinguishing poor, average, and good performance. We next discuss the main findings for each criterion.

\section{Coordination}

An important argument for founding RBOs is that these organizations may enhance coordination between different levels, sectors, and interests, which is key to realizing integrated water resources management (IWRM). In this respect, the RBOs included in our study yield distinctly mixed results. The Mackenzie River Basin Board, an example of a coordinating $\mathrm{RBO}$, performs relatively poorly when it comes to establishing coordination across the basin states. Morris and de Loë (2016) explain how the states may easily bypass the commission, such as in the case of a new joint monitoring program for the tar sands region. In the Thai case study, the coordinating RBOs also perform poorly, and decisions that are crucial for the watershed are taken elsewhere (Ganjanapan and Lebel 2014). The Mackenzie River Basin Board remains dependent on the willingness of contracting parties to conclude bilateral agreements. According to Morris and de Loë(2016) this is because of the institutional design of the RBO, which in turn reflects the political characteristics of the federal state of Canada. This is quite similar to the Australian case study of the Murray Darling River Basin Commission (Ross and Connell 2016) in which the states used to have veto power. However, since the establishment of the Murray Darling Basin Authority, power has shifted to the federal government, and coordination may be achieved by imposing policies on the basin states. Ross and Connell (2016) doubt whether this more coercive approach will yield better results.

The partnership RBOs, the Westcountry Rivers Trust and the Oregon Watershed Enhancement Board and related watershed initiatives, perform rather well. The same goes for the two RBOs that share characteristics with the autonomous RBO type: the German Erftverband and the Portuguese River Basin District Authorities. In the latter case, the RBOs have enhanced coordination within hydrographic basins, but this came at the cost of less coordination across basins at the national level (Thiel and Guerreiro de Brito 2014). 
Table 4. Findings on the performance of the river basin organizations. A rank of "unknown" indicates that no data were available.

\begin{tabular}{|c|c|c|c|c|}
\hline \multirow[b]{2}{*}{ Name of river basin organization } & \multicolumn{4}{|c|}{ Performance measure } \\
\hline & Coordination & Accountability & Legitimacy & $\begin{array}{c}\text { Environmental } \\
\text { effectiveness }\end{array}$ \\
\hline Mackenzie River Basin Board & Poor & Average & Average & Poor \\
\hline Oregon Watershed Enhancement Board & Good & Good & Good & Average \\
\hline Westcountry Rivers Trust & Good & Good & Good & Good \\
\hline Erftverband & Good & Good & Good & Good \\
\hline $\begin{array}{l}\text { Portuguese River Basin District Authorities and } \\
\text { Councils }\end{array}$ & Average & Average & Average & Unknown \\
\hline Breede-Overberg Catchment Management Agency & Good & Average & Average & Unknown \\
\hline $\begin{array}{l}\text { Western Bug River Basin Administration and } \\
\text { Council }\end{array}$ & Poor & Average & Average & Unknown \\
\hline $\begin{array}{l}\text { Lower Kunduz and Taloquan River Basin Agencies } \\
\text { and Councils }\end{array}$ & Poor & Poor & Poor & Poor \\
\hline $\begin{array}{l}\text { Mongolian River Basin Administrations and } \\
\text { Councils }\end{array}$ & Poor & Poor & Average & Unknown \\
\hline $\begin{array}{l}\text { Ping River Basin Committee and Mae Kuang Sub- } \\
\text { basin working group }\end{array}$ & Poor & Average & Poor & Poor \\
\hline $\begin{array}{l}\text { Murray-Darling Basin Authority, Murray-Darling } \\
\text { Basin Ministerial Council, Basin community } \\
\text { committee }\end{array}$ & Average & Average & Average & Unknown \\
\hline
\end{tabular}

The agency type RBOs, which were founded in the Ukraine (Hagemann and Leidel 2014), Afghanistan (Warner and Thomas 2014), and Mongolia (Dombrowsky et al. 2014) with the help of international donor organizations, have been less successful in achieving coordination so far. The reasons for this difficulty are the still powerful hierarchical governmental institutions in place, which hinder cross-sector exchange of information, and the failure to take account of traditional water management practices such as the Abandaz system in Afghanistan. The BreedeOverberg Catchment management agency, however, performs relatively well (Meissner et al. 2016).

\section{Accountability}

Whereas in democracies, general-purpose governments such as provinces, municipalities, or state governments mostly have a directly elected council that is accountable to the public (the electorate), accountability relations of RBOs are more complicated. River Basin Boards or Councils are not directly elected and often consist of representatives of lower levels of government, sometimes supplemented with representatives from nongovernmental organizations or industries. In these cases, the $\mathrm{RBO}$ is accountable to the representatives of the member organizations, which in turn are accountable to their constituencies. Furthermore, the case studies reveal differences between formal accountability and accountability in practice. As Morris and de Loë (2016) explain, the Mackenzie River Basin Board is accountable to the Ministers, but the Ministers are not held accountable for progress made. The case studies of the Breede-Overberg Catchment Management Agency (Meissner et al. 2016), Murray-Darling Basin Authority (Ross and Connell 2016), and the transformation of the Portuguese Water District Administrations into agencies (Thiel and Guerreiro de Brito 2014) all illustrate that centralization enhances accountability of the RBO to the national Ministers and government, but that may come at the cost of accountability to subnational governments (or states within a federal state).
In Ukraine (Hagemann and Leidel 2014), Afghanistan (Warner and Thomas 2014), and Mongolia (Dombrowsky et al. 2014), the RBOs have poor performance in terms of accountability. In the Ukraine case, members of the river basin council are not held accountable. In Afghanistan, informal institutions and practices are far more important than the formal ones. In both the Ukrainian and Mongolian case studies, the respective authors report that corruption in these countries is widespread (Dombrowsky et al. 2014, Hagemann and Leidel 2014; see also Jaspers and Gupta 2014). Again, the Westcountry Rivers Trust (Cook et al. 2016) and the Oregon Watershed Enhancement Board and related watershed initiatives (Lach and Calvert 2014) perform rather well.

\section{Legitimacy}

In the introduction to this special feature, we also raised the question of to what extent RBOs, once founded, enhance the legitimacy of water management policies. The answer to this question is positive for the Oregon Watershed Enhancement Board (Lach and Calvert 2014), the Westcountry Rivers Trust (Cook et al. 2016), and the German Erftverband (Hüesker and Bernhardt 2014). The analysts of these case studies all point to high input and output legitimacy of the RBOs, and perhaps it is no accident that these are all RBOs that operate on a relatively small scale and emphasize collective action. The results for the case studies of the Mackenzie River Basin Board (Morris and de Loë 2016) and the Breede-Overberg Catchment Management Agency (Meissner et al. 2016) show a mixed picture. In the former case, input legitimacy falls short because the contracting parties have historically failed to engage Aboriginal people and make effective use of traditional ecological knowledge, and the output legitimacy is questioned by many. In the latter case, input legitimacy is considered high because of the involvement of a wide range of stakeholders, but it is also low because of persistent major inequalities between stakeholders. The case studies in which international donor organizations played a key role in 
initiating the founding of RBOs, i.e., Ukraine, Afghanistan, Mongolia, and Thailand, show poor to average performance. Hagemann and Leidel (2014) refer to low nongovernmental organization participation in the Ukrainian Western Bug basin, and Warner and Thomas (2014) refer to a lack of support for newly established RBOs and greater support for the much less democratic yet still effective institutions in place. Dombrowsky et al. (2014) are slightly more positive, concluding that Mongolian River Basin Councils, to some extent, have enhanced the legitimacy of river basin policies. Ganjanapan and Lebel (2014) point to the lack of public participation in the Mae Kuang watershed, and Ross and Connell (2016) come to the conclusion that the recently adopted centralized, top-down approach to river basin management in Australia has, to some extent, reduced input legitimacy at regional and local levels.

\section{Environmental effectiveness}

The criterion of environmental effectiveness provided the greatest challenge for the authors participating in this comparative project. In their assessments, they primarily relied on expert judgments, but were faced with several complications, not the least of which is the attribution problem. Because RBOs operate within complex institutional environments in which many other organizations affect the state of water systems through their policies or activities, it is not possible to isolate the effect of contributions made by the RBOs. The authors who studied recent examples of the founding or reform of RBOs obviously argued that it was too early to make such judgments because there is a time lag between the founding of an RBO and the first policies and action plans being drafted, let alone the actual implementation of those plans. However, other authors did find some evidence of environmental effectiveness. In the case of the Murray-Darling basin organization, for instance, a plan was drafted that included comprehensive measures to improve environmental performance, although Ross and Connell (2016) point to the serious risk of implementation failure for the RBO because of distrust between the main actors and the withdrawal of financial contributions by the states. Morris and de Loë (2016) argue that the environmental effectiveness of the Mackenzie River Basin Board is quite low. They suggest that this should not be attributed to a poorly functioning organization per se, but to the institutional design (and specifically, the authority and aggregation rules) of the Board, which leaves all decision-making power with the basin jurisdictions. The environmental performance of the Oregon Watershed Enhancement Board is less clear. Although the Board is generally perceived as successful in stimulating numerous habitat restoration projects, there is no proof of recovery of the salmon population yet (Lach and Calvert 2014); in addition, it is not possible to compare the current approach in Oregon with the state's initially intended approach because that approach was politically unfeasible, potentially suggesting a tension between effectiveness and feasibility.

Similar to the other criteria, the German Erfverband performs well in the view of almost all decision makers and stakeholders. According to Hüesker and Bernhardt (2014), the problem-solving capacity of the Erftverband and similar water boards in the state of North Rhine Westphalia is higher compared to the environmental performance of state's regions where such water boards are absent. The Westcountry Rivers Trust (Cook et al. 2016) also performs well: best management practices are introduced, advice is produced for farmers, landscape restoration is achieved, and farm efficiency savings are made. Ganjanapan and Lebel (2014), however, are rather negative about the effectiveness of the Thai RBOs they studied because, in their eyes, the RBOs avoid difficult allocation issues, and decisions that really matter are taken elsewhere, including by the previously existing institutions. Finally, in the Afghan case study, environmental issues simply have not been recognized at all (Warner and Thomas 2014). However, as in the Thai case, the Afghan case does demonstrate how older institutions sometimes continue to work despite the new layer, so perhaps there is still hope for success.

\section{RELATIONSHIP BETWEEN RIVER BASIN ORGANIZATION DESIGN AND PERFORMANCE: LESSONS LEARNED}

\section{Introduction}

We use the remainder of this article to explore the interrelationship between design and performance. In other words, which design features inhibit or enhance an RBO's performance? This question is as difficult to answer as it is relevant because there are many factors that potentially affect an RBO's performance, and it is difficult to disentangle these factors, let alone assess their relative importance (attribution is difficult). However, we observed several salient patterns that suggest connections between RBO design and performance that deserve attention. In the rich collection of case studies, four factors stand out as being particularly relevant to (re)designing RBOs: (1) institutional interplay or the relationship between the RBO and its broader (previously existing) institutional environment; (2) the ability to generate sufficient resources not only for staffing the $\mathrm{RBO}$, but also for realizing its policies; (3) the dilemma of centralization and decentralization of basin policies; and (4) the time required for RBO reform and impact. Each of these aspects are examined next.

\section{Institutional interplay}

RBOs are examples of special-purpose organizations that are organized on a basin scale. With the exception of the Oregon Watershed Enhancement Board, a case that stands out somewhat in this respect, the geographical scope of each of the RBOs analyzed was at least partially based on hydrological boundaries. Although we saw that administrative, financial, economic, and other pragmatic considerations also play a role in carving out river basin boundaries (see also the section on boundary rules), for the cases included in this study, a claim could be made that the geographical scope of the RBO does correspond, at least to some degree, with the scale at which water management issues manifest themselves. In other words, there is a certain level of fit between the institutions and the bioregions they aim to manage, an outcome that is in line with the international discourse on RBOs. However, at the same time, and quite revealingly, the case studies examined give every indication that the realization of spatial fit between problems and institutions is no guarantee of good performance. In fact, a more influential factor for performance is the relation of the new RBOs to the existing institutional environment, which may be called "institutional interplay" (compare Young 2002). The case studies show that discussions about the foundation of RBOs do not take place in a vacuum; many tasks potentially taken up by a new RBO are normally already performed by existing organizations. In addition, whereas 
many proponents of RBOs hope for "strong" RBOs that take over many of these tasks and integrate them ("institutional displacement" in Thelen's [2004] terms), the reality is that "weak" RBOs with relatively few powers are much more politically feasible in practice. The consequence is that new RBOs are layered on top of existing organizations, and previously existing organizations take varying degrees of control over the new RBOs. Therefore, the RBOs examined were almost always highly dependent on other organizations for realizing their objectives, and their performance was highly dependent on the effective management of institutional interplay. Problematic institutional interplay stands out as a key factor that causes poor RBO performance.

This effect is particularly evident in the cases in which international donor organizations, instead of national or local actors, were the main instigators of institutional change. It would seem that "institutional engineering" by such actors is characterized by a lack of knowledge about the existing structures or a lack of awareness that the relations between these and the new RBO should be defined. Indeed, Hagemann and Leidel (2014:230,224) conclude that in the Ukraine, "[...] the RBOs have been installed within an existing system without having their interrelationship to the other authorities clearly defined," and, about these other authorities, they state, "They keep working on their assigned tasks and follow the old institutional structures from Soviet times. This means they are strictly subordinated to their superiors, particularly the Ministries." Similar observations were made regarding the Afghan case study (Warner and Thomas 2014), where a new formal system was introduced that reflects many traits of the modern IWRM discourse (e.g., the devolution of power and stakeholder participation) but ignores the traditional Abandaz system that continues to influence decision making on the ground. As Warner and Thomas (2014:235) argue, this "pure," imported version of an RBO immediately failed when water allocation problems surfaced and was replaced by a sporadically emerging ad-hoc variety of mixing formal and informal institutions, which performed reasonably well. These findings correspond with Jaspers and Gupta's (2014:56) observation that "many of these discourses [about water governance] are imported into the developing countries and may, on occasion, even be seen as alien to local cultures." Dombrowsky et al. (2014) recognize the relevance of institutional interplay as well. They conclude that the Mongolian democratization and decentralization process, which started in the 1990s, has not been completed yet, a factor that substantially influences RBO performance. Therefore, they suggest that the evolution of the overall governance context is highly relevant to understanding the functioning of the RBOs. Ganjanapan and Lebel (2014:307) also emphasize the relevance of institutional interplay for understanding RBO performance when they argue, "As local administrative organisations have become increasingly important in terms of budget allocation and natural resources management responsibilities within their jurisdictions, it is difficult to plan or manage based on watershed units alone."

Interplay is an issue for Western RBOs as well. Morris and de Loë (2016) basically conclude that the success of the Mackenzie River Basin Board, as an example of a coordinating type RBO, is in the hands of the governments of the participating provinces and territories. One may argue that this is because of the limited competencies granted to the commission by the basin states, but even in the case of the Murray-Darling basin organization, which has more competencies to see through its basin policies, Ross and Connell (2016) point to the relevance of institutional interplay. They argue that it remains to be seen whether the institutional redesign of basin institutions will be successful in the end because the many different parties involved in the implementation of river basin policies have ample opportunities to frustrate the implementation process. These findings relate to the fundamental question posed by Jaspers and Gupta (2014:43) "whether water is a 'sector' in itself or a cross-cutting issue and whether it should be dealt with in relation to its nexus with other sectors and priorities in society." Because the drivers of change in the water sector often arise in other sectors that have other priorities, " $[\ldots]$ this may lead to questioning the very basis of the RBO whose fundamental logic is the hydrological entity encapsulated in a river" (Jaspers and Gupta 2014:58). The experts engaged in RBO design seem to embrace modern water discourses so enthusiastically that they tend to forget to perform sound problem analysis (see also Warner and Thomas 2014) and to take account of the specificities of the institutional environment in which they are working, and thus they underestimate the inertia and pathdependent development of institutions. Given the results of the case studies, we would not go as far to advise against the founding of RBOs at all, but rather to take better account of and establish connectivity with the institutions in place.

\section{Resources}

A second factor that deserves attention is also related to political battles that predate the foundation of RBOs. In practice, the ability of the RBOs to generate resources for both staffing the $\mathrm{RBO}$ and realizing its river basin policies turns out to be very limited. This relates to the pay-off rules that we discussed. The ability to generate resources is a crucial success factor for RBO performance. The Mackenzie River Basin Board has a secretariat with a staff of one person with a rather limited budget, which reflects the (un)willingness of the states to share powers with an RBO (Morris and de Loë 2016). The limited resources and the unwillingness to share power may explain the overall poor performance of this coordinating type RBO. This straightforward argument presents a fundamental structure-agency, or chicken and egg, problem. Of course, one might dream about powerful, integrative, and inclusive RBOs that are also able to generate the necessary resources, but such organizations may only be realized once other actors are willing to share their powers. The case studies show that they generally are not inclined to do so; hence, institutional interplay remains crucial.

We observed some creative examples of resource acquisitions in the cases studied. The Oregon Watershed Enhancement Board has 27 staff members and receives $7.5 \%$ of lottery revenues in Oregon, which makes it a relatively powerful and successful organization (Lach and Calvert 2014). The relatively strong performance of the Westcountry River Trust could partly be attributed to the partnership's ability to mobilize (mainly EU) financial resources successfully (Cook et al. 2016). In the German Erftverband, good performance should partly be attributed to the RBO's ability to generate its own resources through the collection of user and pollution fees (Hüesker and Bernhardt 2014). In sharp contrast with these successful cases is Ukraine: fees collected from water users are all sent to the national government in Kiev, which 
makes only $30 \%$ of the proceeds available for investment in water resources management (Hagemann and Leidel 2014). In the Mongolian case study, the staffing of the RBO is secured through the national budget, but no financial resources have been allocated for drafting and implementing plans. Although new legal arrangements for water pricing and collecting fees were made recently, their implementation is uncertain because watermonitoring institutions are still underequipped and understaffed (Dombrowsky et al. 2014). Ganjanapan and Lebel (2014:312) also point to the relevance of sufficient resources, stating, "The first decade has been largely spent filling and re-filling committees and working groups which rarely meet and have only very modest budgets, little dedicated office support and limited authority." The Australian case is a very specific one because of the increasingly influential role of the water market. The federal government continues to buy water rights as a means to return water resources to environmentally sustainable levels of extraction, and the Commonwealth Environmental Water Holder is expected to become an even more powerful actor in the future. In short, the cases studies reveal different mechanisms for generating resources for staffing RBOs and for implementing basin policies, and because such mechanisms are highly relevant for RBO performance, they deserve attention to be paid to their institutional design.

\section{Dilemma of (de)centralization}

A third common theme running through the case studies relates to the dilemma of (de)centralization. The dilemma, which affects both the effectiveness and the legitimacy of the RBOs, is that centralized and closed decision-making processes may enable the RBO to make good progress and to develop "rational" policies taking into account the hydrological relations within and across large basins. However, such a centralized approach also typically comes at the cost of (input) legitimacy. In contrast, decentralized and open decision-making processes may enhance legitimacy but slow down decision making and lead to suboptimal outcomes at larger scales.

In the case studies presenting longitudinal analyses of $\mathrm{RBO}$ development, we observed parties struggling with this dilemma and quite a bit of oscillation between the two ends of the spectrum. In the South African case study, after major efforts were made to decentralize basin policies and to organize more inclusive processes, the poor progress made with this approach recently triggered a process of increased centralization (Meissner et al. 2016). "[..] there are indications that future CMA [Catchment Management Agency] establishment processes [...] will be conducted by means of more streamlined processes that focus primarily on efficiency and only draw in stakeholders where needed. While this development may speed up the CMA establishment process countrywide, it may have negative consequences for more marginalized stakeholders to participate in the CMA process and to ensure that their interests are represented" (Meissner et al. 2016). In Australia, the lack of results from the interstate Murray Darling Basin Commission was the main reason for the Australian federal state to centralize water management competencies and to establish new Murray Darling basin organizational arrangements (Ross and Connell 2016). Likewise, their poor performance in establishing coordination across basins (besides the predominant hope for financial savings) was an important reason for the Portuguese national government to start reforming the River Basin District Authorities, which are an example of autonomous RBOs, into agency-type organizations again, so as to increase the possibilities for steering and controling these organizations (Thiel and Guerreiro de Brito 2014). The researchers who investigated the Portuguese and Australian case studies express serious doubts about the effectiveness of these changes, mainly because support for the reform by parties who need to implement the new structures is often lacking. Based on these observations, we suggest that parties involved in reform processes should develop a better awareness of the inherent dilemmas of either decentralizing or centralizing basin policies. They would be better to try to compensate carefully for perceived drawbacks of either one of the approaches rather than to organize the system radically once again. This brings us to our final observation, which is on the relevance of time in institutional design processes and assessing RBOs' performance.

\section{Time}

If the discussion on the formation and design of RBOs already shows much signs of political bickering (although not always on the topics we expected), several of the case studies show that this is far from the end of such politicking. Once the organizations have been established, the struggle over their institutional design and performance often continues. The reason for this is that new organizations that are layered on top of existing ones can eventually transform an institutional regime. To prevent that risk from materializing, opponents of RBOs and those with a different view of their appropriate design try to redesign the institutions if they get the chance. However, this means that a certain design has very limited time to settle and to prove itself. Indeed, several authors questioned the speed with which RBOs are being reformed. Basically, their argument is that the system in place was not granted sufficient time to prove effective. As one of the informants on the Mongolian case study states, "The work with the four river basin councils had just started working very well, people were aware of river basin management and integrated water resources management, and then this work was suddenly stopped" (Dombrowksy et al. 2014:284). Likewise, Thiel and Guerreiro de Brito (2014) ask why the seemingly promising River Basin District Authorities were not granted more time to prove themselves, and Ross and Connell (2016) question whether the Murray-Darling Basin Commission was given enough time to become successful. "[... T] The effectiveness of new initiatives has been reduced because initiatives are overtaken or abandoned before they have had time to prove themselves or before they have been properly evaluated" (Ross and Dovers 2008, as quoted by Ross and Connell 2016). These observations underscore our claim that those involved in reform processes should be careful with introducing frequent radical changes.

Our study on the design and performance of different types of RBOs demonstrates that realizing a bioregional approach, which is one of the key prescriptions of adaptive comanagement (Huitema et al. 2009), is not an easy task. It inevitably involves the development of new institutions, which may vary from light coordination structures to the foundation of more powerful organizations. More often than not, these new institutions are perceived as a threat by preexisting institutions, which may not be interested in realizing a bioregional approach. Therefore, the establishment of institutions supporting a bioregional approach is invariably a political process. This implies that the roles and 
tasks of the organizations involved need to be negotiated, and interplay between these organizations needs to be managed. Another design issue that warrants attention is the ability of the institutions to generate sufficient resources both for planning on a bioregional scale and for implementing the necessary measures. Finally, newly established institutions for bioregional management should be granted sufficient time to prove successful, and institutional changes should be based on careful monitoring and evaluation of institutional performance.

To conclude, it seems that the foundation of autonomous or agency type of RBOs has much in common with a Pyrrhus victory. The proponents may be successful in establishing a powerful $\mathrm{RBO}$, but the more power and resources the RBOs has, the more opponents will be inclined to regain power and to hinder the RBO's success. This situation may easily lead to one in which high expectations are not met. It might well be that establishing lighter, coordinating or partnership types of RBOs is a more effective strategy in the long run because such RBOs meet with less resistance.

Responses to this article can be read online at: http://www.ecologyandsociety.org/issues/responses. $\mathrm{php} / 9388$

\begin{abstract}
Acknowledgments:
An earlier version of this article was published as: Meijerink, S., and D. Huitema. 2014. Institutional design, politics and performance of river basin organisations. Pages 356-391 in D. Huitema and S. Meijerink, editors. The politics of river basin organisations: coalitions, institutional design choices and consequences. Edward Elgar, Cheltenham, UK. The authors thank Edward Elgar Publishing for kindly giving permission for the use of this material. We owe a debt of gratitude to the investigators of the various case studies: Michelle Morris and Rob de Loë (Canada); Denise Lach and Dan Calvert (USA); David Benson, Hadrian Cook, and Laurence Couldrick (Great Britain); Frank Hüesker and Christoph Bernhardt (Germany); Andreas Thiel and António Guerreiro de Brito (Portugal); Richard Meissner, Nikki Funke, and Karen Nortje (South Africa); Nina Hagemann and Marco Leidel (Ukraine); Jeroen Warner and Vincent Thomas (Afghanistan); Ines Dombrowsky, Annabele Houdret, and Lena Horlemann (Mongolia); Santita Ganjanapan and Louis Lebel (Thailand); Andrew Ross and Daniel Connell (Australia); and to Frank Jaspers and Joyeeta Gupta for their analysis of the global discourse on river basin organizations.
\end{abstract}

\section{LITERATURE CITED}

Comodomos, G., and J. Ferrer. 2011. Incremental institutional change and Australian universities. International Review of Business Research Papers 7(1):330-339. [online] URL: http://www. irbrp.com/static/documents/January/2011/25.\%20George $\%$ 20Comodromos-FINAL.pdf

Cook, H., D. Benson, and L. Couldrick. 2016. Partnering for bioregionalism in England: a case study of the Westcountry
Rivers Trust. Ecology and Society 21(2):38. http://dx.doi. org/10.5751/ES-08504-210238

Dombrowsky, I., A. Houdret, and L. Horlemann. 2014. Evolving river basin management in Mongolia? Pages 265-297 in D. Huitema and S. Meijerink, editors. The politics of river basin organisations: coalitions, institutional design choices and consequences. Edward Elgar, Cheltenham, UK. http://dx.doi. org/10.4337/9781782549222.00016

Ganjanapan, S., and L. Lebel. 2014. Interplay between new basin organisations, pre-existing institutions and emerging environmental networks in the Mae Kuang watershed, northern Thailand. Pages 298-325 in D. Huitema and S. Meijerink, editors. The politics of river basin organisations: coalitions, institutional design choices and consequences. Edward Elgar, Cheltenham, UK. http://dx.doi. org/10.4337/9781782549222.00017

Hagemann, N., and M. Leidel. 2014. Introducing river basin management in a transitional context: a case study about Ukraine. Pages 210-233 in D. Huitema and S. Meijerink, editors. The politics of river basin organisations: coalitions, institutional design choices and consequences. Edward Elgar, Cheltenham, UK. http:// dx.doi.org/10.4337/9781782549222.00014

Hüesker, F., and C. Bernhardt. 2014. State-founded water boards in industrialised Western Germany. Pages 140-161 in D. Huitema and S. Meijerink, editors. The politics of river basin organisations: coalitions, institutional design choices and consequences. Edward Elgar, Cheltenham, UK. http://dx.doi.org/10.4337/9781782549222.00011

Huitema, D., and S. Meijerink, editors. 2009. Water policy entrepreneurs: a research companion to water transitions around the globe. Edward Elgar, Cheltenham, UK.

Huitema, D., and S. Meijerink, editors. 2014. The politics of river basin organisations: coalitions, institutional design choices and consequences. Edward Elgar, Cheltenham, UK. http://dx.doi. org/10.4337/9781782549222

Huitema, D., and S. Meijerink. 2017. The politics of river basin organizations: institutional design choices, coalitions, and consequences. Ecology and Society 22(2):42. http://dx.doi. org/10.5751/ES-09409-220242

Huitema, D., E. Mostert, W. Egas, S. Moellenkamp, C. PahlWostl, and R. Yalcin. 2009. Adaptive water governance: assessing the institutional prescriptions of adaptive (co-)management from a governance perspective and defining a research agenda. Ecology and Society 4(1):26. [online] URL: http://www.ecologyandsociety. org/vol14/iss1/art26/

Jaspers, F., and J. Gupta. 2014. Global water governance and river basin organisations. Pages 38-66 in D. Huitema and S. Meijerink, editors. The politics of river basin organisations: coalitions, institutional design choices and consequences. Edward Elgar, Cheltenham, UK. http://dx.doi.org/10.4337/9781782549222.00007

Kingdon, J. W. 1995. Agendas, alternatives, and public policies. Second edition. HarperCollins, New York, New York, USA.

Kiser, L. L., and E. Ostrom. 1982. The three worlds of action: a meta-theoretical synthesis of institutional approaches. Pages 179-222 in E. Ostrom, editor. Strategies of political inquiry. Sage, Beverly Hills, California, USA. 
Lach, D., and D. Calvert. 2014. Designing an agency to manage a wicked water problem: the Oregon Watershed Enhancement Board. Pages 96-118 in D. Huitema and S. Meijerink, editors. The politics of river basin organisations: coalitions, institutional design choices and consequences. Edward Elgar, Cheltenham, UK. http:// dx.doi.org/10.4337/9781782549222.00009

Meissner, R., N. Funke, and K. Nortje. 2016. The politics of establishing catchment management agencies in South Africa: the case of the Breede-Overberg Catchment Management Agency. Ecology and Society 21(3):26. http://dx.doi.org/10.5751/ ES-08417-210326

Molle, F., and P. Wester, editors. 2009. River basin trajectories: societies, environments and development. CABI, Wallingford, UK. http://dx.doi.org/10.1079/9781845935382.0000

Morris, M., and R. C. de Loë. 2016. Cooperative and adaptive transboundary water governance in Canada's Mackenzie River basin: status and prospects. Ecology and Society 21(1):26. http:// dx.doi.org/10.5751/ES-08301-210126

Ross, A., and D. Connell. 2016. The evolution and performance of river basin management in the Murray-Darling basin. Ecology and Society 21(3):29. http://dx.doi.org/10.5751/ES-08664-210329

Schlager, E., and W. Blomquist. 2008. Embracing watershed politics. University Press of Colorado, Boulder, Colorado, USA.

Sebenius, J. K. 1992. Challenging conventional explanations of international cooperation: negotiation analysis and the case of epistemic communities. International Organization 46(1):323-365. http://dx.doi.org/10.1017/s0020818300001521

Skelcher, C. 2006. Does democracy matter? A transatlantic research design on democratic performance and special purpose governments. Journal of Public Administration Research and Theory 17(1):61-76. http://dx.doi.org/10.1093/jopart/muj014

Thelen, K. 2004. How institutions evolve: the political economy of skills in Germany, Britain, the United States, and Japan. Cambridge University Press, Cambridge, UK.

Thiel, A., and A. Guerreiro de Brito. 2014. Emergence, performance and transformation of Portuguese water institutions in the age of river basin organisations. Pages 162-183 in D. Huitema and S. Meijerink, editors. The politics of river basin organisations: coalitions, institutional design choices and consequences. Edward Elgar, Cheltenham, UK. http://dx.doi. org/10.4337/9781782549222.00012

Warner, J., and V. Thomas. 2014. River basin organisations in northern Afghanistan: the holy trinity of contemporary water management in practice. Pages 234-264 in D. Huitema and S. Meijerink, editors. The politics of river basin organisations: coalitions, institutional design choices and consequences. Edward Elgar, Cheltenham, UK. http://dx.doi.org/10.4337/9781782549222.00015

Waterman, R. W., and K. J. Meier. 1998. Principal-agent models: an expansion? Journal of Public Administration Research and Theory 8(2):173-202. $\underline{\text { https://doi.org/10.1093/oxfordjournals. }}$ jpart.a024377

Young, O. R. 2002. The institutional dimension of environmental change: fit, interplay, and scale. MIT Press, Cambridge, Massachusetts, USA. 